\title{
Correction to: Affective urbanism: towards inclusive design praxis
}

Tihomir Viderman $^{1} \cdot$ Sabine Knierbein ${ }^{1}$

Published online: 6 May 2020

(c) Springer Nature Limited 2020

\section{Correction to: URBAN DESIGN International (2020) 25:53-62} https://doi.org/10.1057/s41289-019-00105-6.

This article was erroneously published in Volume 25, Issue 1 (2020) https://link.springer.com/article/10.1057/s4128 9-019-00105-6.

The article will be included in the special issue "Guerrilla Urbanism" once the issue is published.

The original article can be found online at https://doi.org/10.1057/ s41289-019-00105-6.

Tihomir Viderman

tihomir.viderman@daad-alumni.de

Sabine Knierbein

knierbein@skuor.tuwien.ac.at

1 Interdisciplinary Centre for Urban Culture and Public Space, TU Wien, Vienna, Austria 


\section{Abstract}

This paper conceptualizes affective urbanism as both research framework and praxis, engaging professionals and concerned publics alike in the insurgent making of cities. With its focus on affect and bodily encounters, it taps into the rich knowledge of practices of improvising and inventing in everyday life, which tend to fall outside the realm of discursive and visual representations. An analysis of spatial practices of the collective Plataforma de Afectados Por La Hipoteca in Barcelona illustrates how a mobilization of affects fosters not only individual, but first and foremost a collective capacity to negotiate belonging, appropriate space and contest alienated conditions of everyday life. The argument rests on the hypothesis that affect implicates the ethical engagement with people at places of everyday life, thus producing a medium and means for transgressing socio-spatial divides and challenging practices of exclusion, othering and dispossession. The value of this kind of work does not necessarily lie in the quality of conceived or materialized design, but rather in enacting an inclusive and empathic design praxis which connects to people's multiple lived spaces and cultivates lived space of deep and caring social relations.

Keywords Affect $\cdot$ Lived space $\cdot$ Embodied space $\cdot$ Spatial practice $\cdot$ Everyday life

\section{What about affect?}

In the wake of the 2008 global financial crisis, about 20 evictions a day were carried out in Barcelona, inciting a series of actions in solidarity with foreclosed people facing an eviction. Mobilized around Plataforma de Afectados por la Hipoteca (PAH, or Platform for People Affected by the Mortgage), activists and concerned publics, many in similar precarious situations, repeatedly gathered in front of foreclosed and auctioned homes, waving banners and making noise, forming human blockades to prevent judicial officials and police from carrying out the evictions. At the same time the involved volunteers invested hard labour into creating a series of respectful spaces of sharing and support for affected people. By engaging in these actions as part of their everyday lives, not only did the activists and involved publics build the agency to improvise and invent against social and economic constraints, but they have also internalized affective experiences. They often refer to the affective dimensions of their collectiviz(ed) actions as a key empowering means in instituting the political project centred on the solidarity values against speculative capitalist urbanization. Their project has eventually become part of the institutional politics. Barcelona En Comú citizen platform, led by Ada Colau, a spokesperson of Barcelona's branch of PAH, won the simple majority in the 2015 municipal election. Since then Colau's municipal government has been committed to renegotiating the meaning of urban places, with a strong reference to everyday life struggles, mundane needs of residents and affective encounters. In view of Colau's (2016a) proclamation that "urbanism is now a battleground, making it impossible to remain neutral", urban design is challenged to engage with space beyond its physical dimensions, extending the focus to its social and democratic aspects.

This paper aims to position affect theories within the field of urban design and planning. The relevance of this endeavour lies in developing an inclusive perspective as regards everyday spatial praxis of urban inhabitants: their collective capacity to negotiate belonging, to appropriate space and to contest structural constraints through practices of improvising and inventing that are part of everyday life. In view of a growing interest in relationality and materiality of the making of places, affect theories contribute a humancentred understanding of how difference is sensed bodily, and how it is constituted, negotiated and mobilized as part of social practices and cultural processes at places of everyday life (Ahmed 2004; Wetherell 2015). Affect is "a transpersonal capacity which a body has to be affected (through an affection) and to affect (as the result of modifications)" (Anderson 2006, p. 735, cited in Pile 2010, p. 8, emphasis in the original). It is therefore a relational phenomenon distributed across both the conscious and the unconscious domain (Wetherell 2015). It derives from encounters and entangles subjects and objects, individuals and their situations, thus interweaving corporeal sensations, stimulations and reactions with the meaning-making, as well as other material and social constructions (Wetherell 2015; Gutiérrez Rodríguez 2011). Beyond the domain of an individual subject, Hardt (2007, p. ix) maintains that affect illuminates actions of political subjects as a synthesis of both "the mind's power to think" (reason) and "the body's power to act" (passion). As such it extends across subjects' power to affect social space and their disposition to be affected by that social space. This means that affect is more than a singular body's reaction or emotional experience, a dimension which is often brought to attention and enhanced in place-making strategies. Its meaning for urban design rather concerns the constitution of social space within which political forces are nurtured and mobilized.

Understood as 'forces of encounter' (Seigworth and Gregg 2010, p. 2), affects "are both within and between bodies". They 'connect bodies' and "[make] them proximate, 
by flowing between them" (Pile 2010, p. 8). In this sense affects may produce a chain impact which can capture certain places and shape the experience of collectivized bodies (Dirksmeier and Helbrecht 2013, pp. 65-67). This dimension has direct implications for how urban space is structured and appropriated. It concerns not only the question of how an action is performed, but also how the action is constituted and how qualitative relations among subjects determine its altering potential. Therefore, the understanding and theorizing of affects offers a more profound insight into social processes and their altering potentials, while providing necessary knowledge for an ethical engagement with people, the overlapping patterns of everyday life and related lived space. Such knowledge promotes a positive attitude to social categories of difference while being attentive to both conscious and unconscious processes of the production of (social) space. The ethical dimension concerns a professional engagement with space through interpersonal encounters and supportive relationships, while reflecting on own positionality and bodily experience regarding a particular urban space. Such an endeavour can in turn empower planners and designers to use their knowledge to address the needs of groups and individuals who tend to be overruled by a dominant paradigm of consensual decision-making.

To develop the argument, the paper situates affect in relation to spatial praxis and broader debates on the spatialized critique of everyday life, suggesting that affect and bodily encounters as part of lived space are taking centre stage in dis-alienation of everyday life: the moments of committed struggle and caring social relations which build collective agency for change. The paper further enquires into practices of the collective Plataforma de Afectados Por La Hipoteca in Barcelona to discuss how affective collective actions reshape meanings and domains of everyday life. Barcelona's collective has opposed institutional politics and financial institutions over their practices of foreclosures and evictions. Collective actions have challenged a prevailing consideration of (seized) housing units as financial assets, with the aim of instead instituting a home as a public, collective and common good. These actions have consisted not only of making political demands for turning foreclosed homes into social housing, but also of using protesting bodies to prevent evictions, or de-privatize seized homes. The paper concludes with a reflection on the affective urbanism as a means of shaping an emancipatory urban space of caring social relations enabling the full development of individual and collective potentials.

The interest in the relationship between the politics of affect and the praxis of urban design and planning had grown out of a workshop excursion to Madrid in February 2015. Titled 'Concepts and critique of the production of space: Growing the seeds of change', it tapped into the rich experience and knowledge of design and planning collectives that engaged in the creation of self-made community spaces of solidarity and opportunity (cf. Knierbein et al. 2015). The ensuing research was carried out from an external perspective between September 2015 and November 2017 inquiring into the spatial praxis of Plataforma de Afectados Por La Hipoteca (PAH) and the spaces it has engaged with. The focus was put on Barcelona where PAH had first been set up, and where it had become part of institutional municipal politics. The paper draws upon qualitative content analysis of secondary sources, including PAH's publications, media reports and scientific articles, complemented with semistructured and informal conversational interviews with local activists, who were selected on grounds of referral or convenience sampling. The narrative analysis of collected data was used to scrutinize what affect means for urban design and planning.

\section{Affect and urban theory}

Social sciences and humanities have engaged conceptually and empirically with affect to overcome unresolved issues of uneven representations in discourse and structural theories, which result from and perpetuate structural inequalities (cf. Schurr and Strüver 2016). Gutiérrez Rodríguez (2011) reminds that affects "are not free-floating energies. They emerge in a space delimited by a concrete historical and geo-political context, structured by inequalities." This means that affects occur in space which is produced through and in turn reproduces asymmetries in power relations. Power, in Foucault's (1978) view, continuously circulates through relations of everyday life, embodied in particular sites, exercised through local institutions and expressed through human bodies. This explains why a place can simultaneously be loved, celebrated, feared, despised or even dismissed by different people. What might inspire excitement in some, can be intimidating for others. Whether a personal bodily experience is empowering or disempowering depends both on structures of power ingrained in space as well as categories of difference. Affect fosters power relations that may be either emancipatory (such as politics of hope) or discriminatory (such as politics of fear). This perspective captures places of everyday life as sites where social inequalities take material form in regard to categories of difference, such as gender, class, race, religion, ethnicity, sexuality, forms of disabilities and impairments.

In Lefebvre's 'Critique of Everyday Life' (2014 [1946]) alienated conditions of everyday life shaped by rational modes of production and consumption are contrasted with quality social relationships based on meaningful experiences of bodily encounters, interaction and exchange. Lefebvre situates affective encounters and body at the heart of his conceptualization of lived space, since they afford individuals 
and groups the agency to challenge patterns and routines of socio-spatial alienation. Lefebvre therefore refers to the social form of space produced through caring relations and affective encounters of emancipated urban dwellers as a site for political resistance and change (Shields 1999, pp. 100-103). Affect theories complement Lefebvre's analytical framework by acknowledging power as immanent to modalities, relations and means through which plural subjects form lived space. This means that the fabric of lived space is loaded with class and gendered structures of oppression, exploitation and struggle (Federici 2011) while also being the site of affective encounters where meaningful change may be nurtured.

Affect falls outside the space of representation of urban design and planning, which is primarily shaped by rational objectivity. As it extends into the emotional realm, affect is considered difficult to visualize or verbalize in a transparent manner (Schurr and Strüver 2016). Yet, being conceptualized as 'wider-than-representational' (Schurr and Strüver 2016), it resonates with both a materiality of socially produced space as well as intangible relations, constellations and configurations of actors, artefacts and processes that shape lived difference. It therefore unlocks a potential for "produc[ing] textured, lively analyses of multiple modes of engagement" beyond the limits of rationalized visual or discursive representations (Wetherell 2013, p. 350).

In view of a spatialized critique of everyday life (Lefebvre 2014 [1946]) and affect theories as 'wider-than-representational' (cf. Schurr and Strüver 2016), affects are seen as an integral part of any meaningful engagement with spatialized structural inequalities (such as unequal access to social and technical infrastructures or exclusion). This paper conceptualizes affective urbanism as the production of shared places of ethical interaction with the Other, thus extending the domain of professional interest beyond curated sentiments of place-making (Friedmann 2010) and selective (regardless of how inclusive) memories of collective heritage (Russell 2007). Affect can inspire professionals to devote their resources to hands-on engagements close to everyday life and needs. At the same time, professional engagement can channel a noteworthy collective energy mobilized by affect into civic initiatives as vanguards of a prolonged hope-filled struggle. At such places a private domain of embodied struggle is being made a matter of public concern (GarcíaLamarca 2017a), while design practices are closely connected to and informed by lived experiences and everyday life struggles (Goonewardena 2011). Affective urbanism can thus transgress socio-spatial divides and boundaries of the modernist tradition of functional separation and fragmentation of urban population.

In terms of a methodological framework, the conceptualization of 'embodied space' (Low 2017) offers a productive means for researching relationships between material urban form and everyday life. Based on the sediment of ethnographic research of a complexity of daily interactions between people and the materialities of urban space, Low (2017) has conceptualized 'embodied space' as a model for interweaving social production and construction of space through a feminist focus on corporality and subjectivity. Embodied space is "the location where human experience, consciousness and political subjectivity take on material and spatial form" (2017, p. 95) and which therefore "can communicate, transform and contest existing social structures" (2017, p. 94). Thrift affirms that embodiment stands for "not just those [social worlds] which are material and extant but those which are ephemeral and possible (Radley 1996, p. 560)" (Thrift 2007, p. 116). Shields (1999) notes that Lefebvre puts the 'lived experience of the body' in the centre of considerations of power relations, structural influence and spatial praxis. For "the body, at the very heart of space, and of the discourse of power is irreducible and subversive" (Lefebvre 1976, p. 89, cited in Shields 1999, p. 76). According to Lefebvre's (2014 [1946]) farsighted account, a balance between repetitive and inventive praxis in everyday life cannot be understood independently from "the relations between bodies, the relations of the corporeal to the spatial and temporal" (Lefebvre 2014, p. 689). In such a view, the body is both a key reference point for studies of urban development (as in many urban design approaches), as well as for the practice of social relations (as in certain urban studies debates). Affective urbanism would span both of these domains: as a means of reflection on the mobilization of affects in everyday life in negotiating more balanced power relations, as well as a field of action and ethical engagement that transforms visionary thinking about egalitarian society into enacted change.

\section{Affect and bodily encounters shaping lived space of struggles}

Largely owing to plural research and activist accounts of the 1960s which reflected on the relation between everyday life and urban design, praxis based theories revolving around spatiality of social relations have permeated urban design and planning. Multifaceted, dynamic and transient experiences of contemporary urban life, which have already occupied the foreground of professional interest across humanities, social sciences and arts, have been introduced into planning and design as relevant subjects of inquiry. Spatial practice has been identified as a point of departure for a qualitative understanding of the transient and endlessly emergent nature of urban space. Yet, MacKenzie and Porter (2017) point to the fact that in many instances everyday life and spatial practice have been depoliticized and turned into a mere spectacle. In Berman's view (1982, pp. 312-328), 
for example, Jacobs's (1992 [1961]) actions for preservation of informality and unpredictability of 'sidewalk ballets' against modernist sanitation principles have become archetypal examples not only of urban activism but also of gentrified urban experience, largely because they had sidestepped racialized and gendered issues of marginalization and exclusion. The notion of depoliticized spatial practice becomes particularly apparent in the proliferation of participatory processes and place-making strategies towards previously pre-determined goals. Affect is a promising framework for addressing such qualitative concerns regarding spatial practice in design and planning. As opposed to bleak outlooks on cities as merely exclusionary economic spaces devoid of plural social qualities, MacKenzie and Porter (2017, pp. 532-536) invoke spaces of everyday life as constituents of political and social relations which are characterized by free movement of thought as well as daily experimentations and struggles containing moments of positive change. This paper hence suggests the focus on affect as a means of challenging depoliticization of (mundane elements of) design and planning.

Approaches such as everyday urbanism (Chase et al. 2008), guerrilla urbanism (Hou 2010) and inclusive and democratic urbanism (Madanipour 2014) have embedded lived space in urban design education and praxis, while accounts such as performative urbanism (Wolfrum and Brandis 2015) and urbanismo afectivo (Knierbein et al. 2015) have added focus on performative and affective dimensions of spatial practice. These accounts develop a critical stance towards functionalist and technocratic approaches, which in their view undermine the capacity of research and planning communities to produce meaningful spaces of affective experience. Many of these approaches suggest that affect and bodily encounters can open the field of urban planning and design to those whose voices are not heard and who seem not to have social, cultural or economic capital to execute power over space. Accordingly, lived space that affirms affect and bodily encounters transcends socio-spatial divisions present in everyday life (Lefebvre 2014).

The public-private divide is one of more prominent principles of embedding socio-spatial boundaries in urban space. Since early theoretical conceptualizations of urban life (cf. Simmel 1903), public and private continue to hover as ubiquitous "social constructs that conceptualize different domains of everyday life-from the interiority and privacy of our bodies and homes to the publicness of city streets and public space" (Gieseking et al. 2014, p. 183). Throughout the modern urban design history, the nature and relationships of private and public have been subject to political, social and economic contestations (Madanipour 2003). The spatial organization of the public-private distinction on a functionalist basis has been a core instrument of the commodification of space, as well as a fundamental principle of instituting social hierarchies and inequalities (Madanipour 2003). In this way the private space of the home was interwoven in public space as a rationalized category of a mono-functional intimate and exclusive housing unit. Shared urban knowledge has consequently been stripped of affective and affected experience of domestic space. Ahmed (2004) also alerts that the emotional domain "has been viewed as 'beneath' the faculties of thought and reason. To be emotional is to have one's judgement affected: it is to be reactive rather than active, dependent rather than autonomous. Feminist philosophers have shown us how the subordination of emotions also works to subordinate the feminine and the body" (Ahmed 2004, p. 3). The feminist tradition has been particularly critical of the fact that "power [is] so often substantiated around a belief that the public and the private are discrete and oppositional domains necessary for organizing social, economic, and political life" (Wright 2010, p. 818, cited in Schur and Strüver 2016, p. 89). The construction of spaces across binaries such as public-private or we-they can be interpreted as a legitimization of practices of inclusion and exclusion with regard to differences in gender, class, race, religion, ethnicity or other (Ajanovic et al. 2015).

Engaged design practices in lived space, such as collectively organized, produced and self-managed urban gardens, workshops or cultural spaces-which regularly come into being through acts of guerrilla-style appropriation-open opportunities for creating commonalities across the public-private distinction or other institutionally grounded boundaries. These design practices radiate care within the collective as well as towards the immediate neighbourhood and a broader society, while being sensitive towards the (social) space they aim to re-appropriate. Such lived space therefore creates capacity for overcoming the silences and absences of those who are not represented and making them visible in an ethical and involved manner. Specifically, lived space of bodily encounters and affect offers a key entry perspective for addressing the issues of representation beyond mere identity politics, as well as for shaping political subjects and nurturing new forms of governmentality (cf. Cvetkovich 2012).

\section{Mobilizing affects in Barcelona: Plataforma de Afectados por la Hipoteca (PAH)}

The Plataforma de Afectados por la Hipoteca (PAH) is one of many highly mobilized socio-political movements that emerged across Spanish cities in the wake of the 2008 global financial crisis. A public discontent erupted over the perceived inability or unwillingness of the political and financial elites to address grievances of a large portion of the public, such as growing unemployment or the defenceless position of people with a mortgage against omnipotent 
financial institutions (cf. Charnock et al. 2012). While the state bailed out troubled banks, no forgiveness of debt was provided for an increasingly vulnerable population. In 2011 a number of insurgencies, in media often referred to as indignados or the $15 \mathrm{M}$ Movement, mobilized through online social networks to fight such unfair institutional practices. Those who felt underrepresented occupied plazas of Spanish cities and put their bodies in protest with the aim of rupturing institutional practices which apparently were inept to reverse surging homelessness, dispossession, unemployment and precarity. For the most part, political struggles have revolved around universal claims for (more) democracy, emancipation, equality or humanity. Beyond these universal categories, PAH succeeded to mobilize diverse publics by articulating a material and seemingly particular issue of housing as one of the most pressing urban matters of public concern (García-Lamarca 2017b).

PAH was first set up in Barcelona in 2009 in solidarity actions with foreclosed people facing an eviction. PAH quickly developed into a grassroots organization consisting of a horizontal network of local assemblies and working groups (commissions) which are organized and acting at the neighbourhood level (cf. García-Lamarca 2017a). Owing to the commitment of a number of volunteers, many of whom having experienced foreclosures and evictions themselves, PAH's support to affected persons and families has continuously developed within three inseparable and mutually reinforcing fields of action. It included horizontal sharing of personal stories and experiences in assemblies, where real people expressed their material and personal struggles, volunteers' support in the form of legal advice, social services and mediation on individual cases with creditors or property owners, as well as the sustained engagement of volunteers 'on the ground' blocking evictions and occupying banks to demand debt forgiveness and occupying vacant bank-owned buildings to turn them into homes for evicted people. As one of the interviewed activists asserts, in light of about 20 evictions a day being carried out in Barcelona in 2009, the number of around 200 people who usually had participated in each action of blocking evictions reflects the vast support that PAH's work has received within society.

Bodily practices of blockade and occupation have produced immediate pressure on property owners (e.g. financial institutions) and transformative influence on legislative and regulatory framework, thus enhancing PAH's negotiation position with institutional actors and paving the way to the introduction of legislative protection measures for vulnerable groups of mortgage debtors. As one of the interviewed activists explained, physical blockades have been primarily intended to postpone evictions, allowing PAH to simultaneously negotiate with the property owner or local government agencies on a social rent or, as the last instance, find an alternative accommodation for evicted persons or families.
While providing legal, social, emotional and action-based support to persons and families facing eviction, PAH has campaigned at the broader urban and national scale for the human and social rights of people affected by mortgage burdens or evictions. PAH argued that legislative and financial institutions, in pursuit of financial gain, disregarded unsettled lived experience of a growing portion of an urban population struggling to service debts in the context of adverse economic developments. The primacy of the economic rationale over social life has produced devastating effects on the urban social fabric. People are put in distress for life, being required to contribute most of their labour to servicing debts, even if they default on their mortgages (cf. Dowsett 2013). Increasing rates of homelessness, suicides and mental disorders were some of the consequences of a policy centred on the protection of financial interests of powerful actors (Colau and Alemany 2012).

PAH's assemblies and blockades have not only contributed to the making of shared spaces of solidarity and material support, but have also played an important role in the emancipation of affected individuals and families. This is where affect was mobilized in building the community's political strength. Instead of hiding their everyday struggle with foreclosures and bankruptcy behind the private curtain of failure and shame, the involved individuals and families have shared their intimate narratives imbued with fears, concerns and guilt. PAH's assemblies and actions have shaped protected places of belonging where distressed people could engage in an affective exchange of lived experiences. By building on solidarity, talking and listening to others, they have reflected on their precarious circumstances of indebtedness as a structurally determined condition affecting many people, which is only marginally influenced by person's decisions and abilities (Colau and Alemany 2012). Moreover, the involved persons have become aware of their agency to fight these restricting structural conditions and induce positive societal changes. They have emerged as knowledgeable political subjects joining in a shared public movement preventing evictions. While not necessarily opposing the institutionalized relations between the creditor and debtor, they have definitely questioned the quality of that relation, claiming that Spain's mortgage and eviction laws favour the powerful over the weak.

With a change of Barcelona's municipal government in 2015 , the struggle for housing is greatly perceived as having moved to the domain of institutional politics. Barcelona En Comú citizen platform won the simple majority in the election. The platform was led by Ada Colau, one of the founding members and until 2014 a spokesperson of Barcelona's branch of PAH. As a new city mayor, Colau appointed some of PAH's key persons to positions within the city's administration. Shared goals and close relations among people have since then blurred the boundaries between city's institutional 
governance and urban activism. At the same time, the interest of broader publics for attending anti-eviction actions has weakened. Interviewed activists emphasized that mortgages were no longer a dominant issue, and that PAH's actions have increasingly turned toward preventing rental evictions. While the number of actions remained stable, the number of people who participate has steadily decreased. In 2017 rarely more than 10 people attended anti-eviction actions. A participation of 30 people is considered a good figure. By timely professionalization, however, PAH has created the necessary base of activists who commit to the exhausting work of keeping the movement going and continue to accumulate territorialized knowledge, which appears to be crucial to how the shift from activism to institutional politics has been made and negotiated.

A prevailing agreement among the interviewed activists is that Colau's administration is mindful of and sensible towards everyday life struggles of Barcelona's residents, yet its scope of action with regard to the housing crisis is considerably restricted by the national level of regulation. Urban policy and the city's programmes engaging in lived social space are therefore often perceived as insufficient for balancing environmental, social and economic challenges. The change in Barcelona's government, however, has unearthed the extent to which political economy of the city, including its publicly owned companies, has been shaped by global financial flows. Spain's national regulatory framework has been criticized for supporting global capital in finding space in Barcelona in spite of delivering rather scarce benefits for urban inhabitants. Colau's administration and activists alike thus claim that cities should have a greater autonomy in defining their means of action, as well as a greater influence in decision-making at the national level of regulation. For it is in the cities where abstract legislative categories meet local corporeal context and where material assistance is provided to people in crisis. This claim is accompanied by an increased feminisation of urban politics (Russel and Reyes 2017). This includes "a political style that openly expresses doubts and contradictions" as well as a broad repertoire of institutional moves, such as the creation of the Department of Life Cycles, Feminisms and LGBTI, committed to promoting equity and fighting discrimination and sexist violence (Russel and Reyes 2017).

Colau's administration has already made use of its territorialized knowledge to proactively engage in shaping economic processes, for example, by regulating and curbing short term rentals that have increasingly dominated Barcelona's tourism sector. Some of the measures that Colau's government uses to ensure a more socially sensible accessibility to housing include a public housing programme centred on both acquisition of properties from banks and new construction, institutionalized rental help schemes as well as institutional procedures for negotiating social rent within bank-owned properties. As a last instance, people who have received an eviction order may request to be placed on the emergency housing list, which is continuously updated according to priorities.

As the mortgage market shrank during the last financial crisis, not only a significant part of the middle class, but also investment funds have moved to the rental market, pushing the rents in Barcelona to unprecedented levels. A liberalization of Spain's residential rental law in 2013 further exacerbated people's struggles to secure a decent home, by reducing the maturity date of tenancy contracts from 5 to 3 years, as well as enabling a landlord to file for an eviction against a tenant who does not pay after just 6 weeks. In light of the persistent and tightened housing crisis, people who have lost homes sometimes seek solution to their housing problems by breaking into and squatting in vacant bank-owned and private properties. Some of the interviewed activists emphasized that, in spite of prejudices, this practice is neither a matter of (alternative) lifestyle nor a political act. Families and individuals who squat see this as their only option to secure somewhat dignified lodging. Squatting practices, however, present an important ideological and political challenge among various groups within PAH. Interviewed activists reminded that while in certain instances some PAH volunteers might assist squatters, PAH generally rejects such practices considering the occupation of buildings the last resort to be used only after other options have been exhausted. Because of politically charged negative connotations, squatters actually risk not receiving support from $\mathrm{PAH}$, in case they at some point turn to PAH for assistance.

PAH's practices have de-normalized everyday realities of struggle that had been considered as given and ordinary. In her analysis, Garcia Lamarca (2017a, p. 5) argues that "fundamental to this is the collective nature of insurgent practice, visible through the material coming together (doings) of bodies in space, for example, through an occupation, as well as through immaterial dynamics (sayings) expressed through sharing knowledge, understanding and affect". PAH's reinterpretation and enactment of housing as a human right provided a valuable impetus for connecting social perspectives with urban design policy and praxis. PAH's actions linked an abstract political struggle concerning alienating urban conditions to the very tangible materiality of the city, while reminding of the dual role that urban design policy plays both in commodifying urban space and in reinstating its use value.

The production of shared urban space and knowledge embracing differences delivers strong emancipatory promises. Such potential is displayed in the documentary 'Sí Se Puede, 7 Days at PAH Barcelona' (Faus 2014), which provided an account of a PAH's week, exposing volunteers' often invisible hard work, while giving voice and face to people struggling for home. The work bodies do to occupy 
space and to rupture routinized political and economic flows is central to conceiving affective action not as a mere solidary practice, but as a strategic counter practice. Interviewed activists of a variety of professional backgrounds agreed that their engagement in spatial actions and supportive networks was meaningful, rendering their professional knowledge as relevant and important. Apart from engaging in the provision of immediate support within PAH, many (young) professionals have expanded the field of action through a series of informal initiatives or even institutional projects, offering a range of empowering opportunities for diverse urban publics. Such opportunities include, for example, community spaces for meetings and various non-commercial activities, open education and engagement workshops based on (enhancing) hands-on skills, production of knowledge with 'invisible' social groups, such as migrant domestic workers. Since mayor Colau took office in 2015, many such initiatives have been included in the institutional framework of providing social support to the city's residents. Activists' focus on accessibility and lived space of bodily encounters also manifests in built urban fabric, as urban design projects rely on robust community engagement to reclaim some of the city blocks' interiors for public use and restrict motorized traffic to selected major thoroughfares.

\section{Conceptualizing affective urbanism}

The imperative of the entrepreneurial paradigm might have delivered on the promise of prosperity for some, but has also diminished social cohesion of cities (Hou and Knierbein 2017). Under the dictate of neoliberal economic doctrines, planning regulations and urban design often disregard asymmetries in power relations within socially produced urban space thus indirectly reinforcing exclusionary spatial configurations. Affective responses to such practices have been articulated in Barcelona's lived space. Engaged publics have employed a variety of approaches, such as guerrilla tactics informed by feminist perspectives, to appropriate urban space for their mostly informal work with concerned individuals and groups, as well as for bringing some of the precarious urban conditions to the attention of the broader society. While evoking the tradition of urban struggles and resistance in the twentieth century, they indeed recall the extent to which urban morphologies have been shaped by practices and discourses of articulated discontent in urban public space.

A former activist, Ada Colau, keeps making headlines even after her daily routine has become a succession of administrative duties in the capacity of Barcelona's first female mayor. Her policies are directed at limiting negative effects of urban capital accumulation, such as the tourist industry, on urban dwellers. While such policies might be considered as important for city's lived spaces, commentators seem to agree that it is her affective relationship with the politics of space that appeals to many (Hancox 2016). Her political style promotes the feminisation of politics, which puts focus on everyday life struggles while nurturing a critical public response to routinized regulatory and economic practices that have seen urban space as a financial product devoid of solidarity.

In 2016 Colau voiced concern that "we still live in sexist and patriarchal cities" because according to her understanding "patriarchy goes hand in hand with the neoliberal city; they are two sides of the same coin" (Colau 2016b). Due to the fact that practices of exclusion, othering and dispossession continue to shape urbanization processes, she foregrounded the city as the place of empowerment of those "who have traditionally been let down" (Colau 2016b). Her endeavours to feminize politics promote affect and emotions (such as empathy) as key political values, alongside reason and rationality that are prevalent in institutionalized planning and design. Hence it can be established that the new municipal politics in Barcelona invokes three additional key moments which carry an emancipatory potential: body, experience and affect. Both PAH and Colau's government have voiced the right to home with the strong reference to experience of everyday life struggles, the needs of sustaining bodies in the city and affective encounters. In regard to this an affective articulation of passions, desires and frustrations emerging from lived experience is seen as a productive means of horizontal capacity building to collectively confront oppression and systematic exploitation of vulnerable social groups.

Affects have been generated, shared and mobilized in Barcelona as insurgent means of resistance to capitalist forces that commodify social space of cities, crush urban solidarity and undermine the political ethics of human and civic dignity. Mortgage affected people, who have been subjected to indebted lives, have voiced seemingly private, yet in fact structural, problems of the mortgage burden, oppression and struggle against unemployment. Spatial praxis of these collectivized bodies has reinstated the use value of urban space nurturing empowering moments of solidarity, exchange and care. The activists' claims extended beyond the right to appropriation of space to the right to influencing public policy, with activists' engagement in the work of city's administration following the 2015 election. Affect has emerged as a currency of political power and change embedded in lived space, as well as a powerful means of contesting, disrupting and transforming routinized practices of representation and policy making. By rendering a private domain of embodied experience a matter of public concern, those who had been under(re)presented, silent and absent in public space have successfully come into focus of broader debates. And in turn, practices of marginalization, 
oppression, exploitation and intimate struggles that belong to the domestic domain would have remained a private problem if their visible bodily presence had not mobilized the action of broader publics.

\section{Conclusion}

Across Europe affects are mobilized for channelling political ambitions into action which can have either affirmative or negative attitude towards the inclusion of difference. What might at first appear as a paradox, affects are propagated across the entire political spectrum, from the radical right to the radical left. Yet, the existing forms of representation, such as political institutions, are entrusted with the duty of preventing the mobilization of affects (for example fear) towards instituting racist or discriminatory mechanisms. This paper argues that urban design and planning alike are important institutions of representation in lived space which have the capacity to foster emancipatory moments and confront exclusionary practices. While affects inscribe a plurality of memories, cultures and experiences into lived space thus imbuing space with meaning, planning and design praxis could play a role in engaging and empowering diverse publics and counteracting the politics of fear.

In his critical reading of Lefebvre's work Purcell (2002) explicitly detaches the political agency of urban inhabitants from "the indirect nature of liberal-democratic enfranchisement in which the voice of citizens is filtered through the institutions of the state" (Purcell 2002, p. 102). He reiterates that "membership in the community of enfranchised people is not an accident of nationality or ethnicity or birth; rather it is earned by living out the routines of everyday life in the space of the city" (Purcell 2002, p. 102). This means that "it is those who live in the city-who contribute to the body of urban lived experience and lived space" who earn the right to appropriation, both in terms of the physical occupation and use of space as well as its structural shaping to meet the needs of its users (Purcell 2002, p. 102). Such a model puts the focus on the political body as a means of reinstating the use value of space and curbing the processes of alienation in everyday life. From the perspective of more-than-representational theories, the embodied subject is the place which mediates between social structures and individual experience (Schurr and Strüver 2016). It constitutes the realm in which the contingency of social structuring becomes noticeable to subjects.

In light of growing media attention given to the themes of financialization of urban infrastructures and urban space at the cost of its lost use value, affect emerges not merely as a fancy concept permeating geography and social sciences, but rather a key ingredient of lived space. It attaches political agency to everyday struggles of ordinary people, which albeit appearing to be disparate and fragmented, provide bodies with the potential for realizing what Dikeç (2001, p. 1790) defines as 'the right to difference'. Difference is understood both as a "right to be different" and "the right to resist/ struggle" (Dikeç 2001, p. 1790). Sandercock (1998, 85ff, p. 129) refers to the "thousand tiny empowerments" which can be nourished by planners and designers who are inclined to cultivate a positive change. Instead of taking a position of an expert loyal to the state, planners and designers can use their knowledge to align, for example, with a community or ethnic minority group, whose needs are often overruled by consensual public decision-making.

To engage in the collective production of knowledge carved by needs and aspirations of diverse publics is to create places of sharing that radiate a sense of care. At such places affective dimensions of social relations are given as much emphasis as their rational aspects. The value of this kind of work does not necessarily lie in the quality of conceived or materialized final design, but rather in enacting an inclusive design process which connects to people's experiences, imaginations and expectations, and thus to their multiple lived spaces. Affective dimensions of this work primarily concern a transformation of mundane politics of everyday life by caring for and reflecting on the cognitive and material manifestations of difference. Such endeavours evidently give primacy to bodily actions in embodied space (e.g. guerrilla urbanism) rather than abstract representations of space such as plans, diagrams or specifications (e.g. zoning plans). Affective urbanism, however, does not exclude either of these modes of engagement. It rather echoes awareness about different dimensions of transformative power that embodied space or representations of space have in mobilizing resources and people, as well as in shaping meaningful places of everyday life. It makes a difference if needs and solutions are articulated collectively by engaging diverse publics in a shared spatial practice, as opposed to inviting discursive participation towards pre-determined planning goals. While giving attention to more-than-representational and affective notions of spatial practice, in particular those which are difficult to convey in words, this epistemology opens disciplinary fields to a range of explorative methodologies and experimental methods which nurture transdisciplinary and empathic learning (cf. Schurr and Strüver 2016).

Even though this argument falls short of discussing how colonial dimensions of the geopolitics of inequality have shaped the production of shared urban knowledge in Barcelona, it maintains that the making of cities centred on public expression of affect bears the potential of disrupting and reconfiguring the socio-spatial hierarchies and divisions. Critical, subversive and guerrilla practices depart from the modernist approaches that understand physical and social space as quantified and distinct categories, which are 
determined through consensual decision-making. They aim at the making of social urban spaces not for but with people who have been affected by structural conditions characterized by deception and failure. Such a lived space includes also those who do not have capital to secure visibility or influence in public space based on rational discourse, thus providing a fruitful basis for carving an inclusive response to the growing challenges of liberal modernity. By expanding their methodologies with affective experiences of collectivized bodies, designers and planners can support self-organization, civic action and meaningful participation. Urban design praxis that has emerged through such a collaborative work is not only embedded in lived space but can also be considered more attentive to a multitude of lived experiences and cultural differences. Affective urbanism, in this sense, helps to turn what is not yet mobilized into a potent transformative force. In this sense, it also helps to understand guerrilla and other affective bodily acts in the field of urban design not just as a reactive critique, but as active and propositional action to designing cities of care.

Acknowledgments Open access funding provided by TU Wien (TUW).

\section{References}

Ahmed, S. 2004. The Cultural Politics of Emotion. New York: Routledge.

Ajanovic, E., S. Mayer, and B. Sauer. 2015. Umkämpfte Räume: Antipluralismus in rechtsextremen Diskursen in Österreich. OZPAustrian Journal of Political Science 44 (2): 75-85.

Anderson, B. 2006. Becoming and Being Hopeful: Towards a Theory of Affect. Environment and Planning D: Society and Space 24 (5): 733-752.

Berman, M. 1982. All That is Solid Melts into Air. The Experience of Modernity. New York: Penguin.

Charnock, G., T. Purcell, and R. Ribera-Fumaz. 2012. ¡Indígnate!: The 2011 Popular Protests and the Limits to Democracy in Spain". Capital \& Class 36 (1): 3-11.

Chase, J.L., M. Crawford, and J. Kaliski. 2008. Everyday Urbanism. New York: The Monacelli.

Colau, A. 2016a. European Prize for Urban Public Space, 4 July, CCCB Barcelona. https://ajuntament.barcelona.cat/alcaldessa /en/speeches/european-prize-urban-public-space. Accessed 13 Mar 2019.

Colau, A. 2016b. After Habitat III: A stronger urban future must be based on the right to the city. The Guardian, 20 October. https ://www.theguardian.com/cities/2016/oct/20/habitat-3-right-cityconcrete-policies-ada-colau. Accessed 23 Oct 2018.

Colau, A., and A. Alemany. 2012. Mortgaged Lives. From the Housing Bubble to the Right to Housing. Los Angeles/Leipzig/London: Journal of Aesthetics and Protest Press.

Cvetkovich, A. 2012. Depression: A Public Feeling. Durham: Duke University.

Dikeç, M. 2001. Justice and Spatial Imagination. Environment and Planning A 33 (10): 1785-1805.

Dirksmeier, P., and I. Helbrecht. 2013. Die Beobachtung der Situation: Zur Rolle von Affekten in Begegnung zwischen Fremden. Geographische Zeitschrift 101 (2): 65-81.
Dowsett, S. 2013. Insight: In Spain, banks buck calls for mortgage law reform. Reuters, 26 February, https://www.reuters.com/artic le/us-spain-mortgage-reform/insight-in-spain-banks-buck-calls -for-mortgage-law-reform-idUSBRE91P09Q20130226. Accessed 13 Nov 2017.

Faus, P. 2014. Sí Se Puede, Seven Days at PAH Barcelona [Documentary]. Comando Video.

Federici, S. 2011. On Affective Labor. In Cognitive Capitalism, Education and Digital Labor, ed. M.A. Peters and E. Bulut, 57-73. New York: Peter Lang.

Friedmann, J. 2010. Place and Place-Making in Cities: A Global Perspective. Planning Theory \& Practice 11 (2): 149-165.

Foucault, M. 1978. The History of Sexuality: An Introduction, vol. 1. New York: Pantheon Books.

García-Lamarca, M. 2017a. From Occupying Plazas to Recuperating Housing: Insurgent Practices in Spain. International Journal of Urban and Regional Research, advance online publication, . https ://doi.org/10.1111/1468-2427.12386.

García-Lamarca, M. 2017b. Reconfiguring the Public through Housing Rights Struggles in Spain. In City Unsilenced, ed. J. Hou and S. Knierbein. New York/London. Routledge: Urban Resistance and Public Space in the Age of Shrinking Democracy.

Gieseking, J.J., W. Mangold, C. Katz, S. Low and S. Saegert. 2014. Section 6, 'Public' and 'Private', Editors' Introduction and Suggestion for Further Reading. In The People, Place, and Space Reader, ed. Ibid. 1st Edition, 183-186. New York: Routledge.

Goonewardena, K. 2011. Critical Urbanism Space, Design, Revolution. In Companion to Urban Design, ed. T. Banerjee and A. Loukaitou-Sideris, 97-108. New York/London: Routledge.

Gutiérrez Rodríguez, E. 2011. Politics of Affects: Transversal Conviviality. Tranversal, European Institute for Progressive Cultural Policies; online: https://transversal.at/transversal/0811/gutierrezrodriguez/en. Accessed 8 Nov 2018.

Hancox, D. 2016. Is this the world's most radical mayor? The Guardian, May 26, https://www.theguardian.com/world/2016/may/26/ ada-colau-barcelona-most-radical-mayor-in-the-world. Accessed 14 Feb 2017.

Hardt, M. 2007. Foreword: What Affects Are Good For. In The Affective Turn: Theorizing the Social, ed. P. Ticineto Clough and J. Halley, 8-13. Durham: Duke University.

Hou, J. (ed.). 2010. Insurgent Public Space: Guerrilla Urbanism and the Remaking of Contemporary Cities. Abingdon: Routledge.

Hou, J., and S. Knierbein (eds.). 2017. City Unsilenced. Urban Resistance and Public Space in the Age of Shrinking Democracy. New York/London: Routledge.

Jacobs, J. 1992 [1961]. The Death and Life of Great American Cities. New York: Vintage Books.

Knierbein, S., E. Krasny, and T. Viderman (eds.). 2015. Urbanismo Afectivo: Concepts and Critique of the Production of Space. Vienna: TU Wien.

Lefebvre, H. 1976. The Survival of Capitalism. Reproduction of the Relations of Production. [Translated by Frank Bryant]. New York: St. Martin's.

Lefebvre, H. 2014 [1946, 1961, 1981]. The Critique of Everyday Life. The One-Volume Edition. London/New York: Verso.

Low, S. 2017. Spatializing Culture: The Ethnography of Space and Place. London: Routledge.

MacKenzie, I., and R. Porter. 2017. Drama Out of a Crisis? Poststructuralism and the Politics of Everyday Life. Political Studies Review 15 (4): 528-538.

Madanipour, A. (ed.). 2003. Public and Private Spaces of the City. London: Routledge.

Madanipour, A. (ed.). 2014. Urban Design, Space and Society. New York: Palgrave. 
Pile, S. 2010. Emotions and Affect in Recent Human Geography. Transactions of the Institute of British Geographers 35 (1): 5-20.

Purcell, M. 2002. Excavating Lefebvre: The Right to the City and Its Urban Politics of the Inhabitant. GeoJournal 58: 99-108.

Radley, A. 1996. Displays and Fragments: Embodiment and the Configuration of Social Worlds. Theory and Psychology 6: 559-576.

Russell, J. 2007. Towards More Inclusive, Vital Models of Heritage: An Australian Perspective. International Journal of Heritage Studies 3 (2): 71-80.

Russel, B. and O. Reyes. 2017. Eight lessons from Barcelona en Comú on how to Take Back Control. Open Democracy, 8 March, https ://www.opendemocracy.net/can-europe-make-it/oscar-reyes-berti e-russell/eight-lessons-from-barcelona-en-com-on-how-to-takebac. Accessed 15 Dec 2017.

Sandercock, L. 1998. Towards Cosmopolis. Planning for Multicultural Cities. Chichester: John Wiley.

Schurr, C., and A. Strüver. 2016. The Rest: Geographien des Alltäglichen zwischen Affekt, Emotion und Repräsentation. Geographica Helvetica 71: 87-97.

Seigworth, G.J., and M. Gregg. 2010. An Inventory of Shimmers. In The Affect Theory Reader, ed. M. Gregg and G.J. Seigworth, 1-26. Durham: Duke University.
Shields, Rob. 1999. Lefebvre. Love and Struggle. Spatial Dialectics. London: Routledge.

Simmel, G. 1903. Die Großstädte und das Geistesleben. In Jahrbuch der Gehe-Stiftung Dresden, vol. 9, ed. T. Petermann, 185-206. Jahrbuch der Gehe-Stftung Dresden: Dresden.

Thrift, N. 2007. Non-representational Theory: Space, Politics, Affect. Abingdon: Routledge.

Wetherell, M. 2013. Affect and Discourse-What's the Problem? From Affect as Excess to Affective/Discursive Practice. Subjectivity 6 (4): 349-368.

Wetherell, M. 2015. Trends in the Turn to Affect: A Social Psychological Critique. Body \& Society 21 (2): 139-166.

Wright, M. 2010. Geography and Gender: Feminism and a Feeling of Justice. Prog. Hum. Geog. 34: 818-827.

Wolfrum, S. and v. Brandis, N. (2015) Performative Urbanism Generating and Designing Urban Space. Berlin: Jovis.

Publisher's Note Springer Nature remains neutral with regard to jurisdictional claims in published maps and institutional affiliations. 